\title{
遠隔口腔粘膜疾患患者相談システムの構築
}

六反田 賢*,**柳 本 惣 市* 鳴 瀬 智 史*
川北晃 子 $^{*}$ 坂 本 由 紀* 梅 田 正 博*

\section{Construction of Remote Consultation System of Patients with Oral Mucosal Disease}

\author{
SATOSHI ROKUTANDA*,*, SOUICHI YANAMOTO*, TOMOFUMI NARUSE*, \\ AKIKO KAWAKITA*, YUKI SAKAMOTO* AND MASAHIRO UMEDA*
}

\begin{abstract}
We have built a remote consultation system for patients with oral mucosal disease via e-mail between the Nagasaki Dental Association and the Department of Oral and Maxillofacial Surgery of Nagasaki University Hospital. The system was initially constructed for providing consultation on whether to refer a patient to the University Hospital, but in many cases it was possible to make a clinical diagnosis by photographs sent via e-mail. Although there some problems remain, such as management of personal information, this system is useful for early diagnosis and treatment of oral diseases.
\end{abstract}

Key words : consultation system (相談システム), dental clinic (歯科医院), university hospital (大学病院), e-mail（電子 メール), early diagnosis (早期診断)

〔Received Apr. 14, 2016〕

\section{緒 言}

遠隔医療は，日本では 1971 年に和歌山県内山間部のへ き地医療モデルとして始まり, 従来の医療サービスを統合 して, 情報通信技術（information and communication technology）を応用した新しい保健医療を提供するシステ ムに発展している1,2)。このことと昨今の情報通信インフ ラの整備により, 近年医科領域では動画, 生体情報, 放射 線画像, 病理画像を通信することによる遠隔診断支援シス テムが実用化されており, 大学病院と地域病院間のみなら ず, 診療所と大学病院間でのインターネットを介した地域 医療ネットワークによる診断支援 ${ }^{3}$ や国境を越えて連携し た報告もみられ4)，テレパソロジー（遠隔病理診断）やテ レラジオロジー（遠隔放射線診断）が日常診療として実用 化され保険導入されている5, 。また，患者に対する遠隔 医療として，テレホームケアー，テレメンタリングについ ても実用化され報告されている7)。しかし，通常初診時の
診査では，医療上の観点から鑑別診断において画像診断が 必要な場合も多く，また，法的な観点から無診察治療禁止 の事項より, 対面診療すなわち病院受診が必要であり ${ }^{7)}$, さらに遠隔医療は情報通信機器の設備費用を必要とするた め, 経済面からも普及が遅れていた。一方, 総務省の 2013 年の調查によれば, わが国のインターネットの利用 者数は 9,652 万人で， 6 歳以上の人口普及率は $79.5 \%$ に向 上してきていることから, 個人情報保護のためのセキュリ ティ対策が必要ではあるが, 遠隔診断を行う上で一般的な インターネットを介することは非常に有用であると思われ る。歯科領域は遠隔診断が難しい分野であると思われるが, これまでにインターネットを用いた医療情報データーベー スと矯正歯科診断支援モデル, 要介護者口腔保健医療ケア システム，在宅患者訪問歯科診療に関する支援システムな どに対する試みが報告されている8-11)。今回われわれは， 長崎県歯科医師会と長崎大学病院口腔外科が連携して構築 した，インターネットを介した電子メールによる遠隔口腔

* 長崎大学大学院医歯薬学総合研究科展開医療科学講座口腔腫瘍治療学分野（主任：梅田正博教授）

** 重工記念長崎病院歯科・ 口腔外科 (主任 : 六反田 賢部長)

* Department of Clinical Oral Oncology, Unit of Translational Medicine, Nagasaki University Graduate School of Biomedical Sciences (Chief: Prof. MASAHIRO UMEDA) 1-7-1 Sakamoto, Nagasaki-shi 852-8102, Japan.

** Department of Oral and Maxillofacial Surgery, Juko Memorial Nagasaki Hospital (Chief: SAToshi ROKUTANDA) 


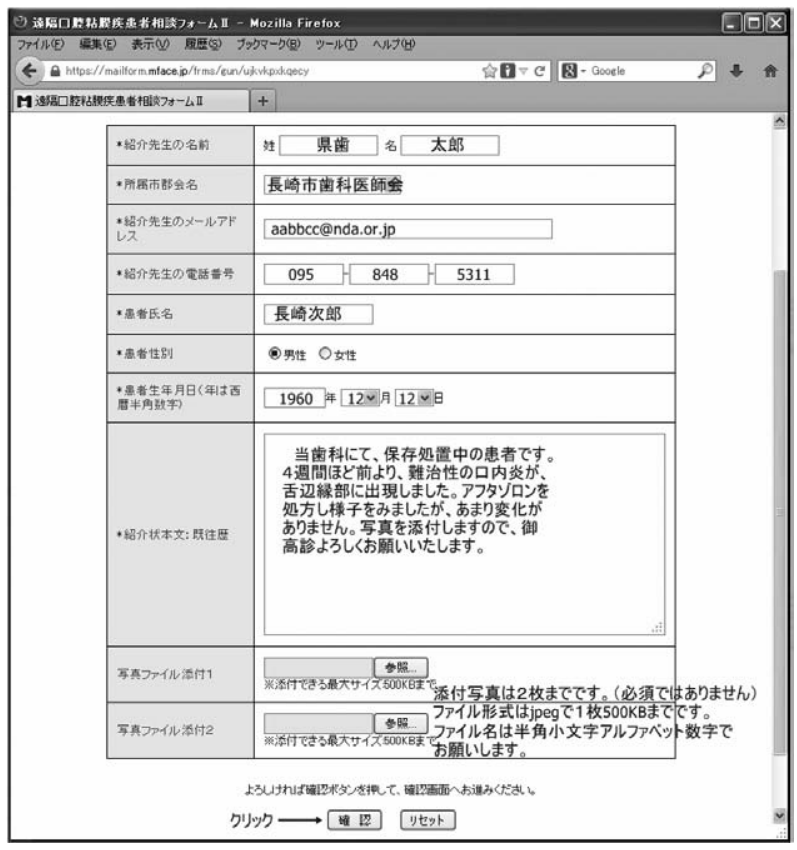

図 1 本システムの送信フォーム（例）

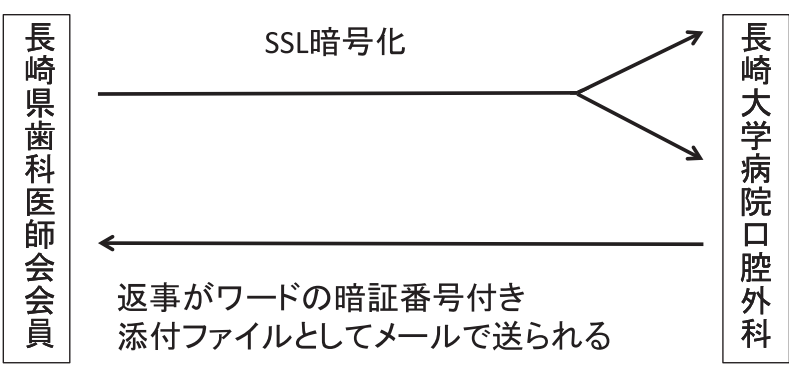

図 2 本システムの概要

粘膜疾患患者相談システムについて報告する。

\section{対象}

対象は 2013 年 7 月より 2016 年 3 月までの奇数月 17 か 月間に,「遠隔口望粘膜疾患患者相談システム」で対応し た 31 例について検討を行った。年齢は 5 歳から 99 歳（平 均 58.9 歳), 性別は男性 12 例女性 19 例であった。

\section{研究方法}

「遠隔口哚粘膜疾患患者相談システム」は, 難治性の口 内炎や診断が困難な口腔粘膜疾患について, 長崎県歯科医 師会会員である歯科診療所の歯科医師が長崎大学病院口腔 外科に診断や治療方針について, 電子メールを用いて相談 できるシステムとして，2013 年 7 月に運用を開始し，長 崎県歯科医師会ホームページに暗号化された電子メールに 本文と 1 枚 $500 \mathrm{~KB}$ までの写真を 2 枚まで添付できる送信 フォームを設置した（図1）。
表 1 「遠隔口腔粘膜疾患患者相談システム」により対応した 症例数

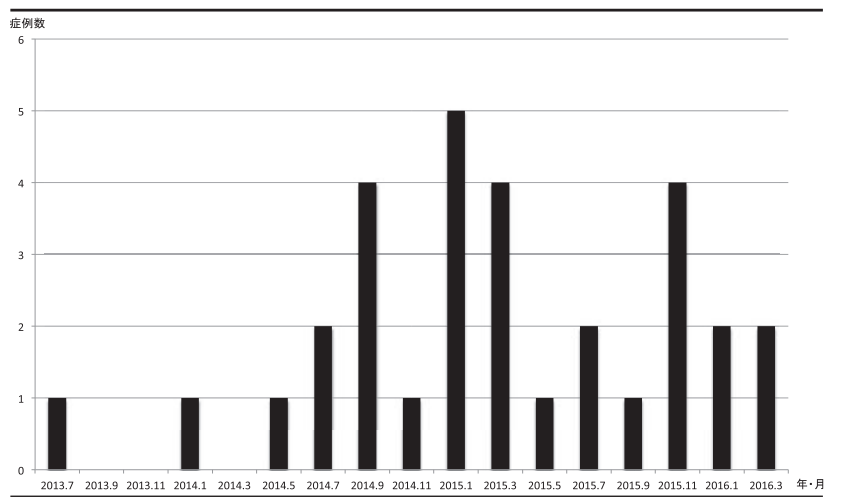

本システムは, 長崎大学病院口腔外科教授 2 名が, 1 か 月交代で送付されてきた電子メールを介した相談に対し回 答している（図 2)。回答者については各教授に限定して いるが，理由はその回答が口腔外科を代表しており，回答 に対して責任を持つ必要があるためである。当科教授は奇 数月を担当しており，当科が対応した症例を調査した。

インターネットを介したシステムを運用するにあたって は，患者情報の漏洩について十分な配慮を行う必要がある。 本システムは患者情報の漏洩防止策として, 以下のような 対策を取った。その内容は, 長崎県歯科医師会のホーム ページより, 相談したい歯科診療所の歯科医師本人がログ イン ID とパスワードを入力して相談フォームを開き，相 談内容の入力を行い, 長崎県歯科医師会事務局に送信する。 その内容が長崎県歯科医師会事務局より長崎大学病院口腔 外科教授に送信される。教授はあらかじめ通知されている ID とパスワードを入力することにより，相談内容を確認 できる仕組みとした。

\section{結 果}

「遠隔口腔粘膜疾患患者相談システム」により対応した 症例数について，2013 年は 7 月に 1 例であった。 2014 年 は 1 月 1 例, 3 月症例なし, 5 月 1 例, 7 月 2 例, 9 月 4 例, 11 月 1 例の計 9 例であった。 2015 年は 1 月 5 例, 3 月 4 例, 5 月 1 例, 7 月 2 例, 9 月 1 例, 11 月 4 例の計 17 例であっ た。 2016 年は 1 月 2 例, 3 月 2 例の計 4 例であった（表 1$) 。$ 年齢は 5 歳から 99 歳 (平均 58.9 歳), 性別は男性 12 例女 性 19 例, 当院口腔外科への受診指示率は $12.9 \%$ であった。 このシステムを通じて当科の口腔外科教授が診断した仮診 断名の内訳は難治性口内炎 9 例, 口腔白板症 5 例, 口腔力 ンジダ症 2 例, tatoo 2 例, 口腔癌, 口腔扁平苔鹰, 白色 海綿状母玟, MRONJ 疑い, 顎骨囊胞疑い, 外骨症疑い, ブランディンヌーン囊胞, 粘液囊胞がそれぞれ 1 例ずつ, その他乳頭腫, 正中菱形舌炎, 異物残存 (残根疑い), 葉 
表 2 「遠隔口腔粘膜疾患患者相談システム」により下した仮診断と患者の年齢，性別，返答に要した時間と当科受 診指示の有無

\begin{tabular}{|c|c|c|c|c|c|}
\hline 症例番号 & 仮診断名 & 年齢 & 性別 & 返答に要した時間 & 当科受診指示 \\
\hline 1 & 口腔カンジダ症 & 31 & 女性 & $3: 16$ & なし \\
\hline 2 & 異物残存 & 45 & 女性 & $0: 44$ & なし \\
\hline 3 & 難治性口内炎 & 51 & 女性 & $3: 57$ & なし \\
\hline 4 & 口腔扁平苔癬 & 72 & 女性 & $2: 28$ & なし \\
\hline 5 & 口腔白板症 & 61 & 女性 & $0: 33$ & なし \\
\hline 6 & MRONJ & 72 & 女性 & $5: 10$ & なし \\
\hline 7 & 色素沈着 & 50 & 女性 & $0: 11$ & なし \\
\hline 8 & 難治性口内炎 & 53 & 男性 & $2: 16$ & なし \\
\hline 9 & 口腔白板症 & 80 & 女性 & $1: 14$ & なし \\
\hline 10 & 難治性口内炎 & 82 & 女性 & $1: 25$ & なし \\
\hline 11 & tatoo & 60 & 男性 & $2: 12$ & なし \\
\hline 12 & 難治性口内炎 & 60 & 男性 & $2: 20$ & なし \\
\hline 13 & 口腔白板症 & 77 & 男性 & 12:09 & なし \\
\hline 14 & 口腔カンジダ症 & 26 & 女性 & $10: 59$ & なし \\
\hline 15 & 口腔白板症 & 93 & 女性 & $1: 26$ & あり \\
\hline 16 & 下唇粘液囊胞 & 5 & 男性 & $2: 43$ & なし \\
\hline 17 & 正中菱形舌炎 & 73 & 女性 & $2: 46$ & なし \\
\hline 18 & 難治性口内炎 & 64 & 男性 & $0: 52$ & なし \\
\hline 19 & tatoo & 40 & 女性 & $2: 26$ & なし \\
\hline 20 & 上顎歯肉癌 & 99 & 男性 & $2: 29$ & あり \\
\hline 21 & 囊胞 & 78 & 男性 & $0: 41$ & なし \\
\hline 22 & 白色海綿状母斑 & 39 & 女性 & $3: 22$ & あり \\
\hline 23 & 口腔白板症 & 85 & 女性 & $1: 00$ & なし \\
\hline 24 & 外骨症 & 61 & 男性 & $0: 53$ & なし \\
\hline 25 & 乳頭腫 & 20 & 女性 & 1:06 & なし \\
\hline 26 & 難治性口内炎 & 55 & 女性 & $3: 32$ & なし \\
\hline 27 & 葉状乳頭 & 52 & 女性 & 19:02 & なし \\
\hline 28 & ブランディンヌーン囊胞 & 24 & 男性 & $2: 59$ & あり \\
\hline 29 & 難治性口内炎 & 69 & 男性 & 3:02 & なし \\
\hline 30 & 難治性口内炎 & 76 & 男性 & $3: 41$ & なし \\
\hline 31 & 難治性口内炎 & 73 & 女性 & 3:05 & なし \\
\hline
\end{tabular}

状乳頭，色素沈着の 5 例であった。返答に要した時間は最 短 11 分, 最長 19 時間 2 分であり, 平均 196.8 分であった。 そのうち 1 時間以内の返答が 7 例, 1 時間以上 3 時間以内 の返答が 15 例だった。(表 2)。MRONJ, 顎骨囊胞, 外骨 症を疑った 3 例については口腔内写真のみでは診断が困難 であったため, 追加検査としてX 線検査を指示していた。

歯科医師会別では, 長崎市 14 例, 大村東彼・佐世保市 がそれぞれ 5 例，諫早市・島原南高・壱岐 2 例，対馬市が 1 例であった。複数回システムを使用している歯科医師は 5 名で，その割合は $30.0 \%$ あった（図 3 )。

以下にこのシステムを使用したことにより確定診断に 至ったまれな白色海綿状母斑の 1 例と, 手術を施行するに 至った口腔がんの 1 例を供覧する。

症例 $1: 39$ 歳, 女性 (写真 1,2$)$ 。

紹介状本文: 左右舌縁部に白色病変がみられ，右側は白
色の遠心部に凹凸が認められます。また, 左右頓側歯肉部, 左右頓粘膜部にも白色の病変が認められます。特に本人に は自覚症状等はありません。

返答：肉眼的にみただけでははっきりとしたことは分か りませんが、かなり広範に白色病変があるように思います。 白板症やカンジダの可能性もありますが，無症状で左右複 数の病変があることから, 白色海綿状母斑のような, かな りまれな疾患の可能性もあります。白色海綿状母斑は私も 数例しか経験したことがない，まれな病変です。特に治療 の必要はないのですが，白板症など前癌病変との鑑別が必 要です。患者さんの同意が得られればできれば大学を受診 していただき，生検等で確認をさせていただければと思い ます。いずれも悪性や前癌性の病変ではないと思います。

生検結果：白色海綿状母斑。

治療：紹介元歯科医院にて経過観察。経過観察中に変化 


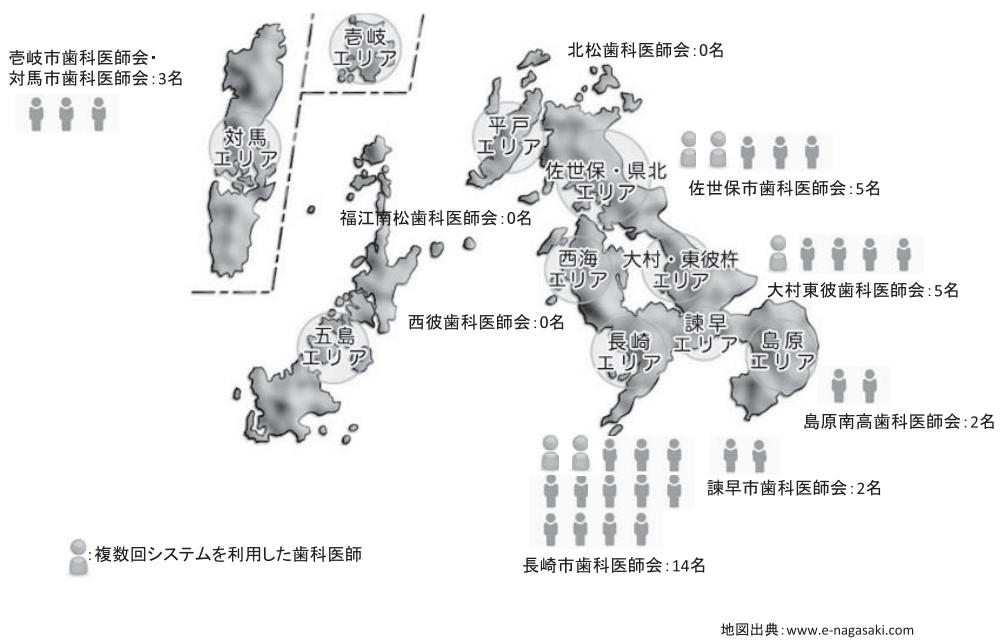

図 3 「遠隔口腔粘膜疾患患者相談システム」を利用した地域別歯科医師数

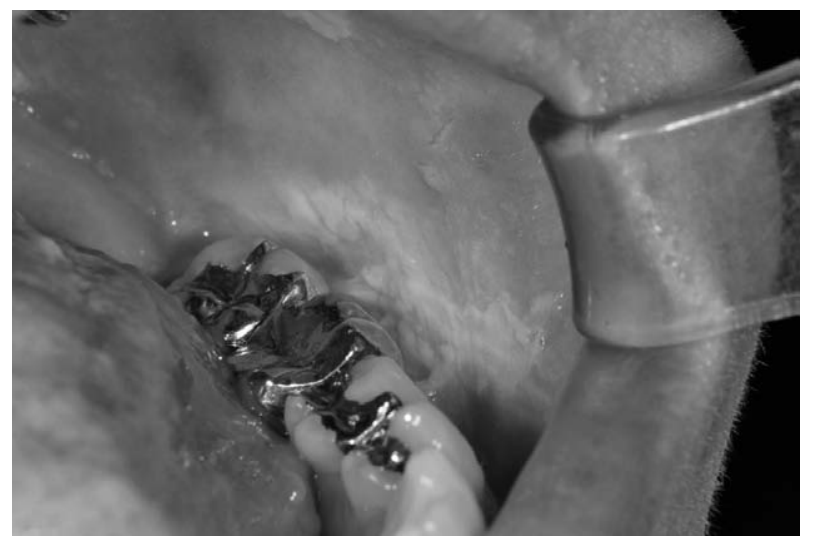

写真 1 症例 1 の左側煩粘膜にみられた白色病変（歯科診療所か ら送付された写真)

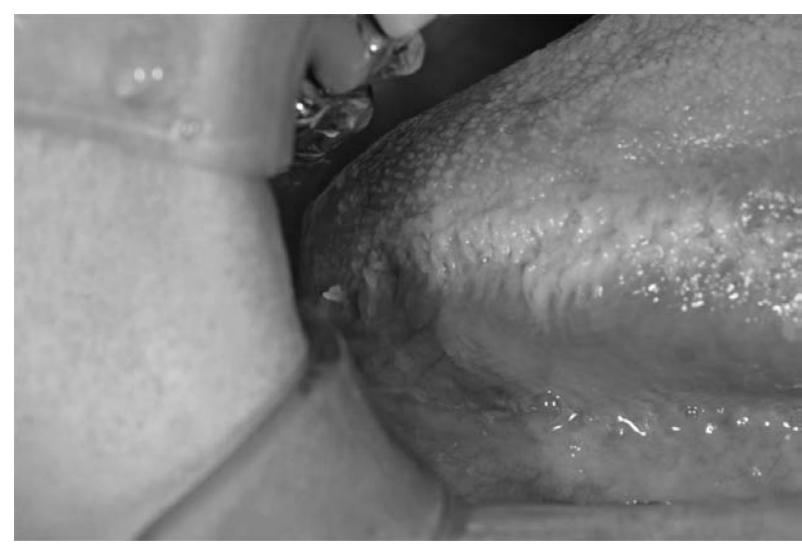

写真 2 症例 1 の右側舌縁部に見られた白色病変（歯科診療所か ら送付された写真)

や異常所見を認めた場合は再度システムを用いて相談する よう指示。

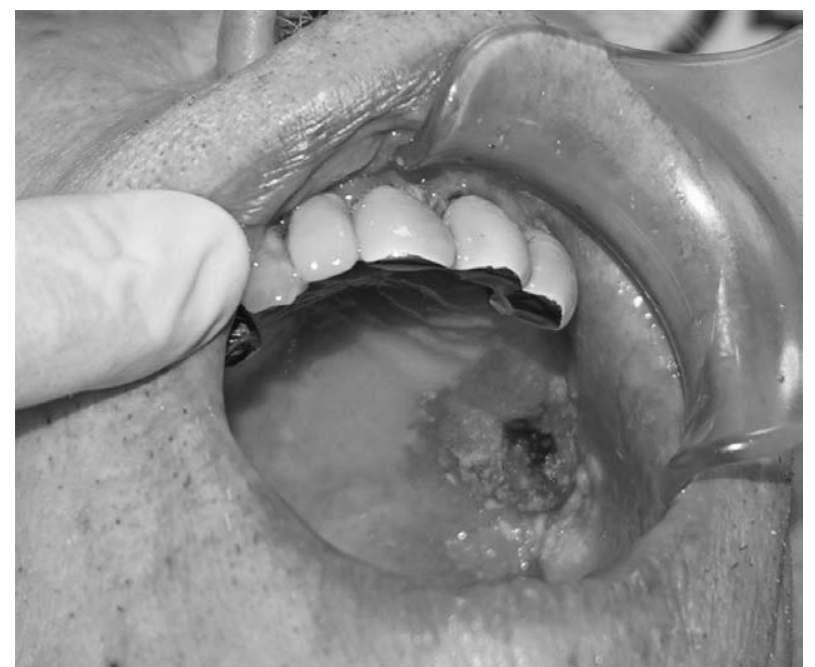

写真 3 左側上顎臼歯部に認められた粘膜病変（歯科診療所から 送付された写真)

症例 2:99 歳, 男性 (写真 3)。

紹介状本文：ご家族より義歯の痛みと口腔ケアを希望と する訪問診療の依頼がきました。早速, 往診にて口腔内検 査したところ, 上顎左側に義歯性の裖瘡性潰瘍と思われる 粘膜疾患。口腔清掃, デキサルチン塗布にて経過観察しま したが, 症状は改善する方向に至らず, 出血を伴う疼痛も あり，今まであまり対応したことのない粘膜疾患と考え， 扁平苔癬や白板症の疑いがあるのではと思い, 今回のご高 診のほどよろしくお願い申し上げます。

返答：おそらく上顎歯肉癌です。1916 年生まれとご高 齢のようですが全身状態や患者さんのご希望によっては非 侵襲的な治療も可能だと思います。もし可能なら大学病院 を受診させていただけないでしょうか？よろしくお願い申 し上げます。 
生検結果：上顎歯肉癌。

治療：腫瘍切除。

\section{考察}

わが国では医師法・歯科医師法第 20 条の原則として, 「患者の診察をしないで治療や診断書等の交付を行っては ならない」と定められており, 遠隔医療がこれに抵触する 可能性が指摘されてきた。これに対して, 厚生労働省より 1997 年に初めて遠隔診療についての通達がなされ，2003 年, 2011 年にそれぞれ一部改正されている。これによると, 基本的考え方として,「診療は, 医師又は歯科医師と患者 が直接対面して行われることが基本であり，遠隔診療は， あくまで直接の対面診療を補完するものとして行うべきも のである」とされ，「直接の対面診療と適切に組み合わせ て行われるときは, 遠隔診療によっても差し支えない」と 示されている。

櫻井ら ${ }^{12)}$ は, 2005 年に新潟県歯科医師会全会員に対し アンケート調査を行い, 歯科医師会会員のインターネット の利用率は $90.1 \%$ でり，一般歯科臨床医は口腔外科分野 を含めた歯科治療全般の診断支援を求める傾向が高かった こと，デジタルカメラの普及率は $33.3 \%$ あっったこと，診 断支援の方法として電子メールを希望する割合が多かった ことを報告している。

長崎県は最も多く有人離島を有し，交通網が十分に整備 されておらず，口腔外科高次医療機関の設置は不十分であ る。そのため口腔外科的疾患の多くは地域の歯科医師が診 断, 治療するものの, 扁平苔痛や白板症, 口腔がんなど粘 膜疾患の診断は困難であるとの意見が多く，より簡便に口 腔外科指導医・専門医に症例を相談できる体制作りが求め られており,「遠隔口腔粘膜疾患患者相談システム」を開 始した。

しかし，本システムはインターネットを介しており，患 者情報の漏洩の危険性を伴う。そのためメール送受信も県 歯科医師会事務局を通じて行い，その開封にはそれぞれに ID とパスワードの入力を課して抢り, 情報漏洩について 十分に対策をとっている。だが，歯科診療所側、大学病院 側いずれも個人のパソコンを用いて相談と返答を行ってお り, それらの機器がウイルス感染などの状況に陥った際に 情報漏洩などの問題が起こる可能性も考えられる。今後更 なるセキュリティ向上のために専用のパソコンを用意する ことも検討すべきであるが，設置費用や外出先への持ち出 しなどの問題もあり今後の検討課題である。大学病院に送 信されてきた画像の保管について, 返答後は医局に設置し ているハードディスクに画像を速やかに移動させ，個人の パソコンのデータを消去している。ハードディスクは医局 内の鍵がかかる棚に保管している。

インターネットを介した遠隔診断を行うためには病態写
真が非常に有用であり, 写真を撮影しパソコンに取り达む ことが容易なデジタルカメラが必要である。送信される写 真の画像品質について, 米国の Practice Guides for teledermatology ${ }^{13)}$ では, 使用するデジタルカメラの画素 数は $1.3 \sim 3$ megapixel が推奨されている。現在わが国で 一般的に販売されているデジタルカメラの画素数は小型軽 量のものでもほとんどが 1.2 megapixel 以上であり, 歯科 で多用されるデジタル一眼カメラにおいても $1.2 \sim 2$ megapixel の機種がほとんどを占めていることから，画素 数については基本的に一般的なカメラを使用して問題ない と思われた。色調については, 稲吉ら ${ }^{14)}$ や村上ら ${ }^{15)}$ が, 肌 の色調の再現性について, 撮影時の照明が十分明るくない など $\mathrm{S} / \mathrm{N}$ 比が低下する条件では, 精度が低下するため分 光方式など光量を増やす工夫が必要であると述べて扮り, Practice Guides for teledermatology ${ }^{13)}$ では Gretag Macbeth Color Chartなどの ColorChecker を使用することを推奨 している。さらに, 画像からの情報のみでは組織の硬さや 圧痛の有無などのようなアセスメントの情報が不明である ため, 対面診療と同等の質の担保には送信元からの文字に よる情報も不可欠であると思われた。口腔内写真を撮影後 は，撮影した写真を $500 \mathrm{~KB}$ 以下に圧縮する必要がある。 カメラの初期設定で撮影した場合, 写真のデー夕量は通常

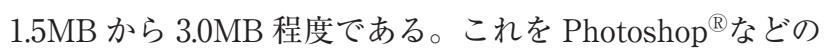
画像編集ソフトウェアを用いて, 論文投稿の際に指定され ることが多い幅 $8.4 \mathrm{~cm}$, 画像解像度を 300 ピクセル / イン 于（dpi）に設定変更すると抄打むね $200 \mathrm{~KB}$ から $400 \mathrm{~KB}$ となり，診断に十分な画質で送信することができる。今回 の検討で, 全症例とも画質の問題は認めなかった。

この「遠隔口腔粘膜疾患患者相談システム」を開始して, 月平均相談症例数は約 1.8 例であった。この数字は決して 多くはないと思われるが開始当初と比較すると安定的にシ ステムを通した相談があり, 大学病院口腔外科への紹介依 頼率は $12.9 \%$ であった。大学病院口腔外科への紹介を依頼 した症例については全て大学病院を受診しており, 本シス テムの目的に対し一定の効果はあると思われた。

このシステムを利用した地域別の相談件数について，比 較的都市部からの相談が多く, 当初想定していた遠隔地か らの相談は予想よりも少数であった。このシステムの周知 は, システム開始時に毎月発行される県歯科医師会会報に より行っており, 遠隔地からの相談が少ない理由として回 答する口腔外科教授と面識がないため相談しにくい環境で ある可能性が考えられた。今後, それぞれの歯科医師会会 員にシステムの概要について直接説明する機会を設け，さ らに相談患者数を増加させるために頻回に会報に紹介文掲 載を行うなど, 更なる周知に務める必要があると思われた。 また, 歯科医師会に属していない歯科医師にも, 必要時に は利用できる様な環境整備を考慮する必要があるとも思わ 
れる。

本システムの有用性について, 複数回システムを使用し ている歯科医師の割合が $30.0 \%$ であた。このことからシ ステムを利用した歯科診療所の歯科医師は, 本システムの 有用性を認識していると思われた。

今回正確な仮診断を下すための情報として, 病態写真 2 枚と文章による情報でおおむね問題は認めなかった。一部 の相談例では追加でX 線検査を依頼したが, その内容か ら碩骨に関連した病変を疑ったためであった。

相談を受ける症例の中には迅速な対応が必要となるもの があるかもしれない。現状では歯科診療所から県歯科医師 会に相談メールが送信されると, その後大学病院へその旨 を知らせるメールが機械的に遅滞なく届くのみで, 特別に 到着を知らせる仕組みはない。そのため対応に要する時間 は受け手である大学病院側により左右される。現在は相談 が送信されたことを認めた時点での仮診断と遅滞ない返信 を心がけているが，歯科診療所側が迅速な返答を希望する 場合には，相談の送信とあわせて電話連絡を行えるような 連絡先の設定, 大学病院側の返答可能な歯科医師数を増や すなどの対策が必要になると思われた。

本来この制度は, 大学病院などの専門機関を受診させる べきかどうかについて相談することを目的にしていたが, 実際には送られてきた病態写真のみでかなり正確な仮診断 が下せる症例が多かった。情報管理などいくつかの問題点 もあるが, 通常では臨床診断が定まらず遠方から大学病院 まで受診しなければならなかった症例についての診療を迅 速化でき, 口腔疾患の早期診断・早期治療にも有用である と思われた。

\section{結論}

今回われわれは, 2013 年 7 月より開始した, 長崎県歯 科医師会と長崎大学病院口腔外科が連携して運用している 「遠隔口腔粘膜疾患患者相談システム」について, ある程 度の症例数を経験したので報告した。今後, 遠隔地の患者 に対する利便性の向上, また判断に苦慮する病態の患者の 診療の一助として, このシステムが広く普及することを期 待している。
謝辞および利益相反 本論文に関連し，開示すべきCOI 状態 にある企業，組織，団体はありません。

\section{引用文献}

1）東まゆみ：臨床応用に向けた遠隔看護（テレナーシング）の 実際と意義. 看護研究, 43:521-531， 2010.

2) Solli, H., Bjork, I.T., Hvalvik, S., et al.: Principle-based analysis of the concept of telecare. JAN, $68: 2862-2815$, 2012.

3）中川 肇，林 隆一：比較的規模の小さい施設を主眼におい た遠隔医療支援システムの構築。医療情報学, 20: 109-114, 2000.

4) Mireskandari, M., Kayser, G., Hufnagl, P., et al.: Teleconsultation in diagnostic pathology: experience from Iran and Germany with the use of two European telepathology servers. J Telemed Telecare, 10:99-103, 2004.

5）大槻昌男：地域医療を変えるテレメディシン IT 遠隔医療 の実践. 女川テレメディシン研究会編著. 東洋経済新報社, 東京, 41-62, 2001.

6）櫻井直樹, 小林 博, 高木律男, 他 : 顎関節症患者遠隔診断 支援システムの開発. 新潟歯学会誌, $37: 43-44,2007$.

7）山口典秀：Skype を利用したアトピー性皮膚炎中医学的漢方 治療の試み TV 電話の活用事例 (中間報告)。 日本遠隔医療 学会雑誌, 2:228-231, 2006.

8）遠藤教昭, 佐藤亨至, 三谷英夫, 他：歯科系大学専門医と開 業医の情報通信に関する研究 インターネットの WWW 用いた矯正歯科診断指導システム. 情報処理学会論文誌, 40:1324-1334, 1999.

9）森川富昭, 西野瑞穂, 有田憲司：病診・病病連携を行うため のリアルタイムコラボレーションシステムの構築一歯科領域 における試行一。医療情報学, $22: 197-205,2002$.

10）河野正司, 石上和男, 片山 修, 他：情報ネットワークを活 用した行政・歯科医療機関，病院等の連携による要介護者口 腔保健医療ケアシステムの開発に関する研究. 厚生労働科学 研究 研究費補助金 長寿科学総合研究事業 平成 $14 \cdot 15$ 年度総括・分担研究報告書, 1-8, 2003.

11）染矢源治, 鈴木一郎, 田中 裕, 他：歯科医師会, 行政, 附 属病院間パソコン・ネットワークによる在宅患者訪問歯科診 療支援システムの開発. 日本歯科医学会誌, $17: 51-62$, 1998.

12）櫻井直樹, 河野正司, 小林 博, 他：ネットワークを活用し た顎関節症患者遠隔診断支援システム構築のための予備的調 査. 新潟歯学会誌, $35: 29-39,2005$.

13) American Telemedicine Association.: Practice guidelines for teledermatology. v1. pp. 14, 2007.

14）稲吉光子, 安達宏幸, 熊田奈津紀 : インターネットを利用し た裖瘡の遠隔診断. 日本裖瘡・オストミー・失禁管理学会誌, $19: 40-45,2015$.

15）村上百合, 小山高史, 山口雅浩, 他：マルチバンド撮影によ る肌の色の推定精度. INNNERVISION, 15：12-16, 2000. 